\title{
A Suggestive Association of Fuchs Heterochromic Cyclitis with Cytotoxic T Cell Antigen 4 Gene Polymorphism
}

\author{
Bernd M. Spriewald ${ }^{a}$ Carolina Lefter $^{b}$ Ilka Huber ${ }^{a}$ Birgit Lauer ${ }^{a}$ \\ Hartmut Wenkel ${ }^{\text {b }}$

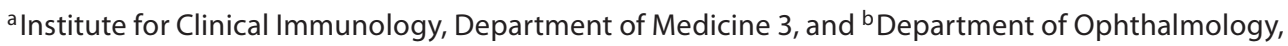 \\ University Erlangen-Nuernberg, Erlangen, Germany
}

\begin{abstract}
Background: Fuchs heterochromic cyclitis (FHC) is a chronic inflammatory eye disease, usually presenting as unilateral anterior uveitis. Up to date no disease susceptibility genes have been described for FHC. Methods: The allele frequency of HLA DRB1 and DQB1, polymorphisms of the tumour necrosis factor (TNF) $\alpha$ promoter region $(-376,-308,-238)$, the promoter $(-318)$, first exon $(+49)$ and (AT)n repeat polymorphism of the cytotoxic T cell antigen 4 (CTLA4) gene were analysed in 44 FHC patients and 139 healthy controls. Results: The CTLA4 $-318 \mathrm{C} / \mathrm{T}$ genotype was increased in FHC patients [odds ratio (OR) 3.0,95\% confidence interval $(\mathrm{Cl})$ 1.4-6.5], as well as long CTLA4 (AT)n microsatellite alleles with more than 16 AT repeats (OR 2.6, 95\% Cl 1.3-5.3). A trend towards the $-308 \mathrm{G} / \mathrm{A}$ TNF- $\alpha$ genotype was found in the patient cohort, whereas no difference in HLA class II allele distribution was observed. Conclusion: CTLA4 but not TNF- $\alpha$ or HLA class II DRB1 and DQB1 may represent a candidate gene for disease susceptibility in FHC.
\end{abstract}

Copyright $\odot 2007$ S. Karger AG, Basel

\section{Introduction}

Fuchs heterochromic cyclitis (FHC) is a chronic inflammatory eye disease, which usually presents as unilateral anterior uveitis of young adults [1]. It was first de- scribed as an affection of the lighter-coloured eye of heterochromic patients. However, the heterochromia can show a wide variation and may even be absent, especially in brown irides [2]. Following an insidious onset, FHC eventually leads to cataract formation and secondary glaucoma. Typically, FHC is not associated with systemic involvement. The aetiology of FHC is still unknown, and several theories have been suggested including an immunological disorder, supported by the detection of increased levels of oligoclonal immunoglobulin $G$ within the aqueous humour of FHC patients [3, 4]. Furthermore, the aqueous humour contains an increased number of $\mathrm{CD} 8+\mathrm{T}$ cells, but fewer CD4+ T cells and macrophages, as compared to patients suffering from idiopathic anterior uveitis [5]. Also $\gamma$-interferon and interleukin 10 were elevated in aqueous humour of FHC patients. These findings were suggested as explanation for the characteristic lack of response to topical steroids in the treatment of FHC $[5,6]$. It has been shown that the CD8+ T cells infiltrating the anterior chamber in $\mathrm{FHC}$ use a restricted $\mathrm{T}$ cell receptor repertoire, implicating an antigen-driven $\mathrm{T}$ cell expansion [7]. Infectious agents such as Toxoplasma gondii or auto-antigens have been discussed as a possible cause or trigger of FHC $[1,8]$. Interesting recent reports provide strong evidence that this antigen might indeed be rubella virus $[9,10]$.

\section{KARGER}

Fax +41613061234 E-Mail karger@karger.ch www.karger.com (c) 2007 S. Karger AG, Basel

0030-3747/07/0392-0116\$23.50/0

Accessible online at:

www.karger.com/ore
Bernd M. Spriewald, MD

Institute for Clinical Immunology, Department of Medicine 3

Glueckstrasse 4a, DE-91054 Erlangen (Germany)

Tel. +499131 853 3092, Fax +49 91318533399

E-Mail bernd.spriewald@med3.imed.uni-erlangen.de 
Table 1. TNF- $\alpha$ and CTLA4 gene polymorphisms in FHC patients

\begin{tabular}{|c|c|c|c|c|c|c|c|}
\hline & \multicolumn{2}{|c|}{$\mathrm{FHC}(\mathrm{n}=44)$} & \multicolumn{2}{|c|}{ Controls $(n=139)$} & \multirow[t]{2}{*}{$\mathrm{p}_{\mathrm{c}}$} & \multirow[t]{2}{*}{ OR } & \multirow[t]{2}{*}{ Power } \\
\hline & $\mathrm{n}$ & $\%$ & $\mathrm{n}$ & $\%$ & & & \\
\hline \multicolumn{8}{|l|}{ Age, years } \\
\hline Median & \multicolumn{2}{|l|}{43} & \multicolumn{2}{|l|}{35} & & & \\
\hline Range & \multicolumn{2}{|c|}{$12-71$} & \multicolumn{2}{|c|}{$28-63$} & & & \\
\hline \multicolumn{8}{|l|}{ Sex } \\
\hline Male & 25 & 57 & 81 & 58 & & & \\
\hline Female & 19 & 43 & 58 & 42 & & & \\
\hline \multicolumn{8}{|c|}{$T N F-\alpha$ promoter $-308 \mathrm{G} \rightarrow \mathrm{A}$} \\
\hline $\mathrm{G} / \mathrm{G}$ & 33 & 75 & 119 & 86 & - & & \\
\hline G/A & 11 & 25 & 17 & 12 & n.s. & $2.4(1.0-5.6)$ & 0.50 \\
\hline $\mathrm{A} / \mathrm{A}$ & & & 3 & 2 & - & & \\
\hline \multicolumn{8}{|c|}{ CTLA4 promoter $-318 \mathrm{C} \rightarrow \mathrm{T}$} \\
\hline $\mathrm{C} / \mathrm{C}$ & 28 & 64 & 117 & 84 & 0.021 & $0.33(0.15-0.70)$ & 0.51 \\
\hline $\mathrm{C} / \mathrm{T}$ & 16 & 36 & 22 & 16 & 0.021 & $3.0(1.4-6.5)$ & 0.51 \\
\hline $\mathrm{T} / \mathrm{T}$ & & & & & - & & \\
\hline \multicolumn{8}{|l|}{$C T L A+49 \mathrm{~A} \rightarrow \mathrm{G}$} \\
\hline $\mathrm{A} / \mathrm{A}$ & 18 & 41 & 46 & 33 & - & & \\
\hline $\mathrm{A} / \mathrm{G}$ & 18 & 41 & 66 & 48 & - & & \\
\hline $\mathrm{G} / \mathrm{G}$ & 8 & 18 & 27 & 19 & - & & \\
\hline \multicolumn{8}{|c|}{ CTLA4 $-318 \mathrm{C} \rightarrow \mathrm{T} /+49 \mathrm{~A} \rightarrow \mathrm{G}$} \\
\hline$-318^{*} \mathrm{~T} /+49^{*} \mathrm{~A}$ & 15 & 34 & 12 & 13 & 0.036 & $3.4(1.4-8.1)$ & 0.60 \\
\hline
\end{tabular}

n.s. $=$ Not significant; $\mathrm{p}_{\mathrm{c}}=$ corrected $\mathrm{p}$ value; $\mathrm{OR}=$ odds ratio; $95 \%$ confidence intervals are given in parentheses.

Although various auto-immune and infectious diseases, including several forms of uveitis, have been strongly linked to HLA antigens, this does not seem to be the case in FHC [11], for which only an association with HLA class II polymorphisms has been suggested [12].

In the present exploratory study we therefore investigated the allele frequency of the HLA class II genes DRB1 and $D Q B 1$. Additionally, polymorphisms of the tumour necrosis factor (TNF) $\alpha$ and cytotoxic $\mathrm{T}$ cell antigen (CTLA) 4 genes were analysed, since both of these genes have been shown to play an important role in auto-immune as well as infectious diseases, and therefore represent candidate genes for disease susceptibility in FHC.

\section{Material and Methods}

\section{Patients and Controls}

Forty-four unrelated patients with FHC were investigated following informed consent. The patients were recruited at the Department of Ophthalmology, University Hospital Erlangen, Germany, and were of Caucasian origin, from the area of south Germany, except for 2 patients from south-east Europe. The allele and genotype frequency of the FHC patients was compared to that of 139 healthy controls, who were all of Caucasian origin, from the area of south Germany. Age and gender distribution is shown in table 1.

\section{Genotyping}

DNA was extracted from peripheral blood samples using the QIAmp DNA blood kit (Qiagen). HLA DRB1 and DQB1 genotyping was performed using the ELPHA low-resolution, PCR singlestrand oligonucleotide typing kit (Biotest AG). This typing scheme allowed the resolution of $D R B 1^{*} 01-{ }^{*} 16$. For HLA $D Q B 1{ }^{*} 02$, ${ }^{*} 0301-{ }^{*} 0303,{ }^{*} 04,{ }^{*} 0501-{ }^{*} 0503$ and ${ }^{*} 0601-{ }^{*} 0609$ were detected. Sequence-based typing for polymorphisms in the genes for TNF$\alpha(-376 \mathrm{G} \rightarrow \mathrm{A},-308 \mathrm{G} \rightarrow \mathrm{A},-238 \mathrm{G} \rightarrow \mathrm{A}), \mathrm{CTLA} 4(-318 \mathrm{C} \rightarrow \mathrm{T}$, $+49 \mathrm{~A} \rightarrow \mathrm{G}$ ) and the (AT)n microsatellite alleles in the $3^{\prime}$ untranslated region of the CTLA4 gene was performed as described earlier [13].

\section{Statistical Analysis}

The Yates-corrected $\chi^{2}$ test for $2 \times 2$ tables and odds ratios (OR) were calculated with $95 \%$ confidence intervals (CI) using SPPS 11.0 (SPSS Inc., Chicago, Ill., USA). p values were subjected to correction according to the Bonferroni inequality method $\left(\mathrm{p}_{\mathrm{c}}\right)$ by multiplication with the number of observed alleles or genotypes. A $p_{c}$ value of 0.05 was considered significant. Power calculations were undertaken for relevant results according to Schles- 
selman [14], based on study size, exposure rate among controls and the relative risk seen in this study, using the method provided by Dupont and Plummer [15]. Similarly, study size calculations were carried out for unmatched case-control studies with equal size for a power of 0.90 and a two-sided level of significance of $\mathrm{p}=0.05$, using the relative risk and the exposure rate among controls obtained in this study.

\section{Results and Discussion}

For the HLA class II alleles, only a slight decrease in $D R B 1^{*} 14$ in the patient cohort was found with $2 \%$ in $\mathrm{FHC}$ patients versus $11 \%$ in healthy controls ( $\mathrm{p}=$ not significant, power 0.44 ). The required study size population to reach a power of 0.9 would be 197 patients in future studies. No further differences in HLA class II allele frequencies were noted in contrast to a previous report [12]. This discrepancy might be due to study size. Additionally, on comparing reports of HLA associations with earlier studies, differences in typing techniques have to be taken into account, since modern genotyping allows more reliable definition of HLA class II antigens than serological typing used until the mid-1990s.

In the TNF- $\alpha$ promoter region, a trend towards an increased frequency of the $-308 \mathrm{G} / \mathrm{A}$ genotype was found in the patient cohort $\left(\mathrm{p}_{\mathrm{c}}=\right.$ not significant, power 0.50 , table 1). In order to reach a power of 0.9 at least 207 patients were required based on the relative risk and exposure rate among controls. The $-308 \mathrm{G} / \mathrm{A}$ genotype corresponds to a high cytokine expressor phenotype [16] and was suggested to influence disease susceptibility in HLAB27-associated uveitis, albeit at a lesser degree than the -238 G/A genotype [17]. However, in our study no further differences were noted for the $-376 \mathrm{G} \rightarrow$ A or $-238 \mathrm{G} \rightarrow$ A promoter polymorphisms (data not shown), suggesting that $T N F-\alpha$ does not play a major role as disease susceptibility gene in FHC.

Next we analysed polymorphism in the CTLA4 gene. CTLA4, also known as CD152, is a homologue of CD28, and both molecules and their common ligands B7-1 (CD80) and B7-2 (CD86) constitute the B7-CD28/CTLA4 co-stimulatory pathway of $\mathrm{T}$ cell activation. Whereas CD28 plays a critical role in T cell activation, CTLA4 constitutes one of the most important inhibitory mechanisms within the immune system [18]. The main pathway utilised by CTLA4 is competition with CD28 for ligands and inhibitory signalling [19]. On analysis of the CTLA4 promoter we found an increase in the $-318 \mathrm{C} / \mathrm{T}$ genotype frequency in the FHC cohort compared to controls (OR 3.0, 95\% CI 1.4-6.5), whereas no differences for the +49
$A \rightarrow G$ polymorphism in exon 1 were seen (table 1 ). On analysis of the (AT)n microsatellite, 23 different alleles were detected, ranging from 7 to 33 repeats. (AT)7 and (AT)16 were observed most frequently with 42 and $23 \%$ of all individuals, respectively. This finding is in accordance with previous observations [20]. No differences in the distribution of single (AT)n alleles between the patient and control cohort were observed (data not shown). For further analysis, alleles with up to 16 AT repeats, representing the most frequently observed alleles in both cohorts, were defined as short (S) and alleles with more than 16 repeats as long $(\mathrm{L})$. In the FHC cohort an increase in $\mathrm{L}$ alleles was observed (OR 2.6, 95\% CI 1.3-5.3), and reciprocally a reduction in the $\mathrm{S} / \mathrm{S}$ genotype compared to healthy controls (OR 0.38, 95\% CI 0.19-0.77, table 2). There was also a trend towards an increased frequency of the S/L genotype in the FHC group, which became more obvious when it was analysed in conjunction with the $-318 \mathrm{C} / \mathrm{T}$ genotype (OR 4.3, 95\% CI 1.7-11.0, table 2). The earlier suggested linkage of long CTLA4 microsatellite alleles with the $+49^{*} \mathrm{G}$ allele [21] was not observed in our study cohort, where the long microsatellite alleles were found similarly often in the absence or presence of the $+49 * \mathrm{G}$ allele (data not shown). For both, $-318 \mathrm{C} \rightarrow \mathrm{T}$ and $+49 \mathrm{G} \rightarrow$ A CTLA4 polymorphisms, functional implications have been demonstrated in vitro, with respect to expression levels of CTLA4 and subsequent T cell reactivity [22-24]. The $-318^{*} \mathrm{~T}$ as well as the $+49 * \mathrm{~A}$ allele were associated with increased CTLA4 expression [24, 25] and were considered alleles protective against auto-immune disease [26]. In the present study, individuals carrying both the $-318^{*} \mathrm{~T}$ and $+49^{*} \mathrm{~A}$ alleles protective against auto-immune disease were overrepresented within the FHC cohort (OR 3.4, 95\% CI 1.4-8.1, table 1), whereby all but 1 patient with the $-318^{*} \mathrm{~T}$ allele also carried the $+49^{*} \mathrm{~A}$ allele, in contrast to controls who showed this association in only 12 out of 22 cases. However, since overall 36 of the 44 patients carried the $+49^{*} \mathrm{~A}$ allele, this might be due to incidental co-distribution, either in cis or trans position, or might represent a true linkage disequilibrium.

It has been suggested that the common functional variants of the CTLA4 gene may have been subject to evolutionary selection in host resistance to infection, with auto-immune disease susceptibility alleles providing increased cellular immunity compared to auto-immune resistance alleles [26]. It is therefore tempting to speculate that the cellular immune response and clearing of rubella virus, the suspected trigger of FHC $[9,10]$, may be impaired in these patients. A prolonged persistence of $\mathrm{ru}^{-}$ bella virus has been described for certain FHC patients, 
Table 2. CTLA4 (AT)n microsatellite polymorphism in FHC patients

\begin{tabular}{|c|c|c|c|c|c|c|c|c|}
\hline & & \multicolumn{2}{|c|}{$\mathrm{FHC}(\mathrm{n}=44)$} & \multicolumn{2}{|c|}{ Controls $(n=139)$} & \multirow[t]{2}{*}{$\mathrm{p}_{\mathrm{c}}$} & \multirow[t]{2}{*}{ OR } & \multirow[t]{2}{*}{ Power } \\
\hline & & $\mathrm{n}$ & $\%$ & $\mathrm{n}$ & $\%$ & & & \\
\hline \multicolumn{9}{|c|}{$\begin{array}{l}(A T) n \text { microsatellite } \\
\text { Allele }\end{array}$} \\
\hline \multirow{2}{*}{\multicolumn{2}{|c|}{$\begin{array}{l}\text { S (short, } \mathrm{n} \leq 16) \\
\mathrm{L} \text { (long, } \mathrm{n}>16)\end{array}$}} & 38 & 86 & 127 & 91 & - & & \\
\hline & & 29 & 66 & 59 & 42 & 0.022 & $2.6(1.3-5.3)$ & 0.50 \\
\hline \multicolumn{9}{|c|}{ Genotype } \\
\hline S/ & & 15 & 34 & 80 & 58 & 0.033 & $0.38(0.19-0.77)$ & 0.50 \\
\hline S/ & & 23 & 52 & 47 & 34 & n.s. & $2.1(1.1-4.3)$ & 0.50 \\
\hline $\mathrm{L} /$ & & 6 & 14 & 12 & 9 & - & & \\
\hline \multicolumn{9}{|c|}{$-318 C \rightarrow T \quad(A T) n$ microsatellite } \\
\hline $\mathrm{C} / \mathrm{C}$ & $\mathrm{S} / \mathrm{S}$ & 13 & 30 & 75 & 54 & 0.048 & $0.36(0.17-0.74)$ & 0.50 \\
\hline $\mathrm{C} / \mathrm{C}$ & $\mathrm{S} / \mathrm{L}$ & 12 & 27 & 37 & 27 & - & & \\
\hline $\mathrm{C} / \mathrm{C}$ & $\mathrm{L} / \mathrm{L}$ & 3 & 7 & 5 & 4 & - & & \\
\hline $\mathrm{C} / \mathrm{T}$ & $\mathrm{S} / \mathrm{S}$ & 2 & 5 & 5 & 4 & - & & \\
\hline $\mathrm{C} / \mathrm{T}$ & $\mathrm{S} / \mathrm{L}$ & 11 & 25 & 10 & 7 & 0.018 & $4.3(1.7-11.0)$ & 0.50 \\
\hline $\mathrm{C} / \mathrm{T}$ & $\mathrm{L} / \mathrm{L}$ & 3 & 7 & 7 & 5 & - & & \\
\hline
\end{tabular}

n.s. = Not significant; 95\% CI are given in parentheses.

albeit without correlation with CTLA4 genotypes [9]. Unfortunately no data on rubella virus infection were available on patients in our cohort in order to further assess this possible connection, which will be an important objective for future studies.

Whether the potential role of CTLA4 as disease susceptibility gene in FHC can simply be attributed to altered gene function becomes arguable when the (AT)n repeats are taken into account. An influence of the (AT)n microsatellite alleles on CTLA4 expression levels has also been demonstrated in vitro, whereby long (AT)n microsatellite alleles resulted in impaired mRNA stability and reduced expression of CTLA4 in vitro. Altough this effect of the (AT)n repeats on CTLA4 expression was less obvious in vivo [27], it would counteract the suggested influence of the $-318^{*} \mathrm{~T}$ and $+49^{*} \mathrm{~A}$ alleles. This points to the current difficulty in translating CTLA4 polymorphisms to altered gene function, partly being due to the complexity of CTLA4 expression [18]. However, it is interesting to note that similar genetic associations for CTLA4, an increase in $-318^{*} \mathrm{~T}$ and longer (AT)n microsatellite alleles were observed with Wegener's granulomatosis [28, 29], an auto-immune disease characterised by necrotising granulomatous lesions and small-vessel vasculitis. Here- by CTLA4 expression in unmanipulated peripheral $\mathrm{T}$ helper cells was increased, but impaired following stimulation [30]. Whether a similar effect can be observed in FHC patients will be subject to further studies.

In summary, the data of this initial exploratory study suggest that CTLA4 but not TNF- $\alpha$ or HLA class II DRBI and $D Q B 1$ represents an interesting candidate gene for disease susceptibility in FHC. However, these data will have to be reproduced in a larger patient cohort, preferably a multi-centre study, in order to meet the recommendations on genetic association studies also for rare diseases such as FHC [31]. 


\section{References}

1 Jones NP: Fuchs' heterochromic uveitis: an update. Surv Ophthalmol 1993;37:253-272.

2 Becker MD, Zierhut M: Fuchs uveitis syndrome - Heterochromia is no 'conditio sine qua non'. Ophthalmologe 2005;102:733742

3 Murray PI, Hoekzema R, Luyendijk L, Konings S, Kijlstra A: Analysis of aqueous humor immunoglobulin $\mathrm{G}$ in uveitis by enzymelinked immunosorbent assay, isoelectric focusing, and immunoblotting. Invest Ophthalmol Vis Sci 1990;31:2129-2135.

4 Bloch-Michel E, Lambin P, Debbia M, Tounsi Y, Trichet C, Offret H: Local production of IgG and IgG subclasses in the aqueous humor of patients with Fuchs heterochromic cyclitis, herpetic uveitis and toxoplasmic chorioretinitis. Int Ophthalmol 1997;21: 187-194.

5 Muhaya M, Calder V, Towler HM, Shaer B, McLauchlan M, Lightman S: Characterization of T cells and cytokines in the aqueous humour $(\mathrm{AH})$ in patients with Fuchs' heterochromic cyclitis (FHC) and idiopathic anterior uveitis (IAU). Clin Exp Immunol 1998; 111:123-128.

6 Muhaya M, Calder VL, Towler HM, Jolly G, McLauchlan M, Lightman S: Characterization of phenotype and cytokine profiles of $\mathrm{T}$ cell lines derived from vitreous humour in ocular inflammation in man. Clin Exp Immunol 1999;116:410-414.

7 Labalette P, Caillau D, Grutzmacher C, Dessaint JP, Labalette M: Highly focused clonal composition of CD8(+) CD28(neg) T cells in aqueous humor of Fuchs heterochromic cyclitis. Exp Eye Res 2002;75:317-325.

8 La Hey E, Broersma L, van der Gaag R, Baarsma GS, Rothova A, Kijlstra A: Does autoimmunity to $\mathrm{S}$-antigen play a role in Fuchs' heterochromic cyclitis? Br J Ophthalmol 1993;77:436-439.

9 Quentin CD, Reiber H: Fuchs heterochromic cyclitis: rubella virus antibodies and genome in aqueous humor. Am J Ophthalmol 2004; 138:46-54

10 de Groot-Mijnes JD, de Visser L, Rothova A, Schuller M, van Loon AM, Weersink AJ: Rubella virus is associated with Fuchs heterochromic iridocyclitis. Am J Ophthalmol 2006;141:212-214.

11 Goverdhan SV, Lotery AJ, Howell WM: HLA and eye disease: a synopsis. Int J Immunogenet. 2005;32:333-342.
12 De Bruyere M, Dernouchamps JP, Sokal G: HLA antigens in Fuchs' heterochromic iridocyclitis. Am J Ophthalmol 1986;102:392393.

13 Spriewald BM, Witzke O, Wassmuth R, Wenzel RR, Arnold ML, Philipp T, Kalden JR: Distinct tumour necrosis factor alpha, interferon gamma, interleukin 10, and cytotoxic $\mathrm{T}$ cell antigen 4 gene polymorphisms in disease occurrence and end stage renal disease in Wegener's granulomatosis. Ann Rheum Dis 2005;64:457-461.

14 Schlesselman JJ: Case-Control Studies: Design, Conduct, Analysis. Oxford, Oxford University Press, 1982.

15 Dupont WD, Plummer WD Jr: Power and sample size calculations: a review and computer program. Control Clin Trials 1990;11: 116-128.

16 Abraham LJ, Kroeger KM: Impact of the -308 TNF promoter polymorphism on the transcriptional regulation of the TNF gene: relevance to disease. J Leukoc Biol 1999;66: 562-566.

17 El-Shabrawi Y, Wegscheider BJ, Weger M, Renner W, Posch U, Ulrich S, Ardjomand N, Hermann J: Polymorphisms within the tumor necrosis factor-alpha promoter region in patients with HLA-B27-associated uveitis association with susceptibility and clinical manifestations. Ophthalmology 2006;113: 695-700.

18 Gough SC, Walker LS, Sansom DM: CTLA4 gene polymorphism and autoimmunity. Immunol Rev 2005;204:102-115.

19 Teft WA, Kirchhof MG, Madrenas J: A molecular perspective of CTLA-4 function. Annu Rev Immunol 2006;24:65-97.

20 Rodriguez MR, Nunez-Roldan A, Aguilar F Valenzuela A, Garcia A, Gonzalez-Escribano MF: Association of the CTLA4 $3^{\prime}$ untranslated region polymorphism with the susceptibility to rheumatoid arthritis. Hum Immunol 2002;63:76-81.

21 Holopainen PM, Partanen JA: Technical note: linkage disequilibrium and disease-associated CTLA4 gene polymorphisms. J Immunol 2001;167:2457-2458.

22 Ligers A, Teleshova N, Masterman T, Huang WX, Hillert J: CTLA-4 gene expression is influenced by promoter and exon 1 polymorphisms. Genes Immun 2001;2:145-152.

23 Maurer M, Loserth S, Kolb-Maurer A, Ponath A, Wiese S, Kruse N, Rieckmann P: A polymorphism in the human cytotoxic $\mathrm{T}$ lymphocyte antigen 4 (CTLA4) gene (exon 1 +49) alters T-cell activation. Immunogenetics $2002 ; 54: 1-8$.
24 Wang XB, Zhao X, Giscombe R, Lefvert AK: A CTLA-4 gene polymorphism at position -318 in the promoter region affects the expression of protein. Genes Immun 2002;3: 233-234.

25 Anjos S, Nguyen A, Ounissi-Benkalha H, Tessier MC, Polychronakos C: A common autoimmunity predisposing signal peptide variant of the cytotoxic T-lymphocyte antigen 4 results in inefficient glycosylation of the susceptibility allele. J Biol Chem 2002; 277:46478-46486.

26 Ueda H, Howson JM, Esposito L, Heward J, Snook H, Chamberlain G, Rainbow DB, Hunter KM, Smith AN, Di Genova G, Herr MH, Dahlman I, Payne F, Smyth D, Lowe C, Twells RC, Howlett S, Healy B, Nutland S, Rance HE, Everett V, Smink LJ, Lam AC, Cordell HJ, Walker NM, Bordin C, Hulme J, Motzo C, Cucca F, Hess JF, Metzker ML, Rogers J, Gregory S, Allahabadia A, Nithiyananthan R, Tuomilehto-Wolf E, Tuomilehto J, Bingley P, Gillespie KM, Undlien DE, Ronningen KS, Guja C, Ionescu-Tirgoviste C, Savage DA, Maxwell AP, Carson DJ, Patterson CC, Franklyn JA, Clayton DG, Peterson LB, Wicker LS, Todd JA, Gough SC: Association of the $\mathrm{T}$-cell regulatory gene CTLA4 with susceptibility to autoimmune disease. Nature 2003;423:506-511.

27 Wang XB, Kakoulidou M, Giscombe R, Qiu Q, Huang D, Pirskanen R, Lefvert AK: Abnormal expression of CTLA-4 by $\mathrm{T}$ cells from patients with myasthenia gravis: effect of an AT-rich gene sequence. J Neuroimmunol 2002;130:224-232.

28 Huang D, Giscombe R, Zhou Y, Lefvert AK: Polymorphisms in CTLA-4 but not tumor necrosis factor-alpha or interleukin lbeta genes are associated with Wegener's granulomatosis. J Rheumatol 2000;27:397-401.

29 Giscombe R, Wang X, Huang D, Lefvert AK: Coding sequence 1 and promoter single nucleotide polymorphisms in the CTLA-4 gene in Wegener's granulomatosis. J Rheumatol 2002;29:950-953.

30 Steiner K, Moosig F, Csernok E, Selleng K, Gross WL, Fleischer B, Broker BM: Increased expression of CTLA-4 (CD152) by T and B lymphocytes in Wegener's granulomatosis. Clin Exp Immunol 2001;126:143-150.

31 Anonymous: Freely associating. Nat Genet 1999;22:1-2. 